\title{
The Mycoplasma hominis P120 membrane protein contains a 216 amino acid hypervariable domain that is recognized by the human humoral immune response
}

\author{
Charlotte Nyvold, $\uparrow$ Svend Birkelund and Gunna Christiansen
}

Author for correspondence: Gunna Christiansen. Tel: +45 89421749. Fax: +4586196128. e-mail : chlam@biobase.dk

Department of Medical Microbiology and Immunology, The Bartholin Building, University of Aarhus, DK-8000 Aarhus C, Denmark
In the antigenically heterogeneous species Mycoplasma hominis a monoclonal antibody, mAb 26.7D, was previously found to recognize a $120 \mathrm{kDa}$ polypeptide from $M$. hominis 7488. This antibody did not react with the type strain PG21. The homologous gene from M. hominis PG21 was cloned and sequenced and found to have a sequence identity of $91 \%$ with the gene of strain 7488. One hypervariable and two semivariable regions were detected. The epitope for mAb 26.7D was mapped to the hypervariable domain by expression of various parts of this domain in Escherichia coli using expression vector systems. A polyclonal antiserum (PAb 121) generated against the hypervariable region of P120 from PG21 identified the P120 homologue in $M$. hominis PG21. Fusion proteins of the hypervariable and constant parts of the proteins were constructed and tested for reactivity with 21 human sera. Twelve sera reacted with the $\mathbf{7 4 8 8}$ hypervariable fusion protein, but only four reacted with the PG21 hypervariable fusion protein. No reactivity was seen with a fusion protein containing part of the constant region of P120. Gene fragments amplified from $18 \mathrm{M}$. hominis isolates by PCR confirmed the heterogeneity of the hypervariable domain. Based on restriction endonuclease cleavage patterns of the hypervariable domain the 18 isolates could be divided into four classes. Reactivity with both mAb 26.7D and PAb 121 confirmed these classes. The hypervariable, but not the constant, part of P120 was recognized by the human humoral immune response. Such a variable domain may be important in evasion of the host's immune response, and thus aid survival of the micro-organism.

Keywords: Mycoplasma hominis, $120 \mathrm{kDa}$ antigen, antigenic variation, membrane protein

\section{INTRODUCTION}

Mycoplasmas are the smallest known self-replicating prokaryotes. The genome size is small, ranging from $580 \mathrm{kbp}$ in Mycoplasma genitalium ( $\mathrm{Su} \&$ Baseman, 1990) to $1300 \mathrm{kbp}$ for Mycoplasma iowae (Grau et al., 1991). The $G+C$ content is low, varying from 23 to $41 \mathrm{~mol} \%$ (Razin \& Freundt, 1984). Mycoplasma

†Present address: Department of Clinical Immunology, K17631, Rigshospitalet, National University Hospital, Copenhagen, Denmark.

The GenBank accession numbers for the sequences determined in this work are: U22017, U22018, U22019, U22020, U22021, U22022, U22023, U22024, U22025 and U22026. hominis is usually found as part of the normal flora of the human urogenital tract (Krause \& Taylor-Robinson, 1992), but has frequently been associated with gynaecological disorders, postpartum fever, neonatal infections, and extragenital infections of varying severity (Tully, 1993). The association has generally been based on isolation of the micro-organism, as the pronounced heterogeneity of $M$. hominis isolates makes serology less reliable. Heterogeneity in the size of the reacting antigens of different isolates has been demonstrated by use of immunoblotting (Brown et al., 1983; Birkelund \& Andersen, 1988) and thus identification of specific antigens is difficult. Specific pathogenicity factors have not been described. 
Isolates of M. hominis show considerable heterogeneity. Analysis of $14 \mathrm{M}$. hominis strains examined by twodimensional gel electrophoresis (Andersen et al., 1987) showed that $41-72 \%$ of their proteins were in common. Christiansen \& Andersen (1988) also found pronounced heterogeneity among $M$. hominis strains when 26 strains were examined for heterogeneity by restriction fragment length polymorphism using parts of rRNA genes as probes. These results were confirmed by Blanchard et al. (1993), who found remarkable differences within the $16 \mathrm{~S}$ rRNA genes of $M$. hominis strains.

Heterogeneity of $M$. hominis membrane proteins has been studied by use of monoclonal antibodies (mAbs) (Christiansen et al., 1990; Ladefoged et al., 1990; Olson et al., 1991). Cytoplasmic proteins were conserved, while surface-exposed proteins showed a high degree of antigenic variation.

We have previously described cloning and sequencing of a gene from $M$. hominis 7488 encoding a $120 \mathrm{kDa}$ surface-exposed protein. The protein is probably a lipoprotein because it has a cleavage site for signal peptidase II (Christiansen et al., 1994). The $120 \mathrm{kDa}$ membrane protein has a surface-exposed epitope recognized by $m A b 26.7 \mathrm{D}$. This $m A b$ reacted with the $120 \mathrm{kDa}$ protein $(\mathrm{P} 120)$ in 11 of $19 \mathrm{M}$. hominis isolates but did not react with the type strain, M. hominis PG21. However, DNA probes from the gene (termed p120) encoding P120 hybridized to DNA from all $19 \mathrm{M}$. hominis strains including PG21, and on the chromosomal maps of five M. hominis strains (PG21, 4195, 132, 93 and 7488) the $p 120$ gene was located at similar positions close to the gyrB gene (Ladefoged \& Christiansen, 1992). To study whether this variable, surface-localized protein was recognized by the human humoral immune response we studied this system in detail.

The aims of this study were to determine the genetic basis for the variable reactivity with $\mathrm{mAb} 26.7 \mathrm{D}$, to identify the regions of sequence variability in $p 120$ in different strains of $M$. hominis, and to examine the human humoral immune response to variable and constant domains of P120.

\section{METHODS}

Bacterial strains, growth media and plasmids. The two groups of $M$. hominis isolates used were described previously by Christiansen \& Andersen (1988). The isolates from group 1 (selected to show a high degree of heterogeneity), but not those from group 2 (local clinical isolates), were filter-cloned (Tully, 1983). M. hominis, which is arginine-metabolizing, was cultivated in BEa medium [heart infusion broth (Difco), $2.2 \%(\mathrm{w} / \mathrm{v})$; horse serum, $15 \%(\mathrm{v} / \mathrm{v})$; fresh yeast extract, $1.9 \%(\mathrm{w} / \mathrm{v})$; benzylpenicillin, $40 \mathrm{IU} \mathrm{ml}^{-1}$; L-arginine, $0.23 \%$ $(\mathrm{w} / \mathrm{v})$; phenol red $0.0023 \%(\mathrm{w} / \mathrm{v})]$. The $\mathrm{pH}$ of the medium was adjusted to $7 \cdot 2$ and the medium was sterilized by filtration (Christiansen \& Andersen, 1988). Escherichia coli XL1-Blue (Stratagene) and E. coli $\mathrm{INV} \alpha \mathrm{F}^{\prime}$ (Invitrogen) were used for transformation. The cloning vector pBluescript $\mathrm{SK}(+)$ (Stratagene) was used for shotgun cloning of genomic DNA.
For cloning of PCR products the pCRII vector (Invitrogen) was used, and for production of fusion proteins the expression vector pGEX-5X-3 (Pharmacia) was employed.

Patient sera. Patient sera were obtained from the World Health Organization Reference Bank for Reproductive Immunology, Institute of Medical Microbiology, University of Aarhus, Denmark. The samples were originally collected for investigation of unexplained infertility. The collection contained 195 sera, 21 of which on the basis of an indirect haemagglutination assay for detection of antibodies to $M$. hominis, were selected for this study.

Preparation of DNA. DNA was isolated from the M. hominis strains using the method described by McClenaghan et al. (1984). M. hominis cells were harvested and lysed on ice in a buffer containing $0.7 \% \quad(\mathrm{w} / \mathrm{v}) \quad N$-laurylsarcosine, $10 \mu \mathrm{g}$ RNase $\mathrm{ml}^{-1}$ (Sigma), $20 \mathrm{mM}$ Tris pH 7.5 and $20 \mathrm{mM}$ EDTA. Proteinase $\mathrm{K}\left(150 \mu \mathrm{g} \mathrm{ml}^{-1}\right)$ was added and the cell lysate was incubated at $55^{\circ} \mathrm{C}$ for $2 \mathrm{~h}$ and at $37^{\circ} \mathrm{C}$ for $1-2 \mathrm{~h}$ followed by phenol, phenol/chloroform, and chloroform extractions (Sambrook et al., 1989). Plasmids from transformed E. coli were prepared by the alkaline lysis method described by Sambrook et al. (1989).

Cloning of $M$. hominis DNA in pBluescript. Genomic $M$. bominis DNA was digested with restriction enzymes (Boehringer Mannheim) according to the supplier's recommendations. The cleaved DNA was ligated to pBluescript SK $(+)$ DNA (Stratagene) cut in the polylinker region as described by Sambrook et al. (1989). E. coli XL1-Blue was transformed with recombinant plasmids by electroporation $(2500 \mathrm{~V}, 25 \mu \mathrm{F})$ using a gene pulser transfection apparatus (Bio-Rad). The positive clones were detected by colony hybridization according to Sambrook et al. (1989), using probes from the $p 120$ gene from $M$. bominis 7488 (Christiansen et al., 1994).

Agarose gel electrophoresis and Southern blotting. DNA was separated in $0.7 \%$ agarose gels [Agarose NA, Pharmacia; $0.5 \mathrm{mg}$ ethidium bromide $\mathrm{I}^{-1}$ and Tris/borate/EDTA (TBE) buffer]. DNA was transferred to Hybond- $\mathrm{N}$ membranes $(0.45 \mu \mathrm{m}$, Amersham) as described by Southern (1975). DNA fragments were labelled with $\left[\alpha^{32}\right.$ P]dATP (Amersham) by nick-translation as described by Sambrook et al. (1989).

Silver-stained polyacrylamide gel. Tru9I-digested PCR products were separated in $10 \%$ polyacrylamide gels according to Sambrook et al. (1989). Silver staining of the acrylamide gels was done with Bio-Rad Silver Stain according to the manufacturer's instructions.

DNA sequencing. Sequencing was carried out on doublestranded DNA using the dideoxynucleotide chain-termination method of Sanger et al. (1977). The Sequenase sequencing kit (United States Biochemical) was used according to the manufacturer's instructions. Primers (SK, KS, T3 and T7) recognizing base sequences in the pBluescript $S K(+)$ vector were used. In addition, primers based on the DNA sequences obtained of M. hominis 7488 and M. hominis PG21 were synthesized and used (DNA Technology).

Preparation of RNA from M. hominis PG21 and Northern blotting. M. hominis PG21 cultures were harvested in the early-exponential phase (when colour change of the medium was first detectable) at $19000 \mathrm{~g}$. Total RNA was purified by the single-step method of Chomczynski \& Sacchi (1987). Cells were solubilized in buffer D (4 M guanidinium thiocyanate, $25 \mathrm{mM}$ sodium citrate, $0.5 \%$ Sarkosyl and $0.14 \mathrm{M} \beta$-mercapto- 
Table 1. Primer sets used for PCR

\begin{tabular}{|c|c|c|}
\hline Nucleotide sequence & $\begin{array}{l}\text { Position on the } \\
\text { p } 120 \text { gene }\end{array}$ & $\begin{array}{c}\text { Size of DNA } \\
\text { fragment (bp) }\end{array}$ \\
\hline \multicolumn{3}{|c|}{ Primer sets used for PCR on the $M$. hominis strains DC63, V2785, SC4, PG21, 7488 and 4712} \\
\hline 5'-CGGAATGGTTTCAGGTGGACCCCTTCG-3' & -387 to -361 & 485 \\
\hline $5^{\prime}$-GCTGCCATAGGCATTAAGGCTGCTACGC-3' & 70-97 & \\
\hline $5^{\prime}$-TGAGGACTTAAAAGCCC-3' & $584-600$ & 382 \\
\hline 5'-GTGTCTTGCCGCTGC-3' & $951-965$ & \\
\hline 5'-GAAGCAGCGGCAAGACAC-3' & $948-965$ & 445 \\
\hline 5'-CTTGGAATAGTCTGCC-3' & $1377-1392$ & \\
\hline $5^{\prime}$-GGTCTTAAAACAGACC-3' & $2067-2082$ & 323 \\
\hline 5'-GAGAAGTATGGGTCAAC-3' & 2373-2389 & \\
\hline $5^{\prime}$-GGATTCTATGGCACAC-3' & $2583-2598$ & 502 \\
\hline 5'-GATCCATCATAACTGCC- $3^{\prime}$ & $3068-3084$ & \\
\hline $5^{\prime}$-GAACAGCTAAATATCAAGC- $3^{\prime}$ & $316-334$ & 561 \\
\hline 5'-CGTCATATTCTTTGTCTAGTGC-3' & $855-876$ & \\
\hline 5'-CAAAACTTGAAATTGAAGTTGC- $3^{\prime}$ & $769-790$ & 460 \\
\hline 5'-GCATTTCCTCAAGAAAATGTAGGG-3' & $1205-1228$ & \\
\hline 5'-ATGATGCCTCATTAACGAGCG-3' & $1102-1122$ & 567 \\
\hline 5'-GGTCTTTTTCAGTTAATCC-3' & $1650-1668$ & \\
\hline \multicolumn{3}{|c|}{ Primer set used for PCR of the hypervariable domain of $p 120$ on the $18 \mathrm{M}$. hominis strains } \\
\hline 5'-GCTATTGTTGAAATTCC-3' & $357-373$ & 696 \\
\hline 5'-CTTTGATTGTTCAGCAGTAGG-3' & $1032-1052$ & \\
\hline
\end{tabular}

ethanol), followed by RNA extraction with water-saturated phenol. After extraction, RNA was precipitated with ethanol, and stored at $-20^{\circ} \mathrm{C}$. For Northern blotting analysis, RNA was electrophoretically separated on agarose gels containing formaldehyde, and transferred as described by Sambrook $e t$ al. (1989). Standards used were $16 \mathrm{~S}$ and $23 \mathrm{~S} \mathrm{rRNA}$ and lambda DNA cleaved with HindIII.

DNA amplification by PCR. Eight sets of oligonucleotide primers (DNA Technology) were synthesized to amplify fragments of the $p 120$ gene from different $M$. hominis strains. The oligonucleotide primer sequences, the positions of the amplified DNA fragments on the $p 120$ gene and the sizes of the PCR products are shown in Table 1 . The first five primer sets were based on the sequence of strain 7488 while the last three primer sets were based on that of PG21. PCR was performed in a volume of $100 \mu \mathrm{l}$ with 2 units of Taq polymerase (Boehringer), $100 \mathrm{pmol}$ of each primer, $0.2 \mathrm{mM}$ of each of dATP, dTTP, dGTP and dCTP, $1 \times$ Taq polymerase buffer (Boehringer) and $0 \cdot 1 \mu \mathrm{g}$ template DNA. A cycle of $94^{\circ} \mathrm{C}$ for $1 \mathrm{~min}, 45^{\circ} \mathrm{C}$ for $1 \mathrm{~min}$ and $72^{\circ} \mathrm{C}$ for $1 \mathrm{~min}$ was repeated 30 times in a thermal cycler (Perkin Elmer Cetus). After the last cycle a final extension temperature of $72{ }^{\circ} \mathrm{C}$ was maintained for $10 \mathrm{~min}$. The PCR products were analysed in $2 \%$ agarose gels or in $10 \%$ polyacrylamide gels. The PCR experiments were repeated at least twice and results were consistent.

Generation of fusion proteins. The nucleotide sequences of the primers used for amplification of part of the hypervariable domain of $p 120$ of $M$. hominis PG21 were: 5'-GGATCCTAAGTAGCTTAGAGACCAAGC-3' (bases 424-444 with the BamHI site added) and $5^{\prime}$ CTCGAGATTAGCTTCAATTTCTTTAG-3' (bases 820839 with the $X$ hoI site added). For amplifying part of the hypervariable domain of $p 120$ of $M$. hominis 7488 (Christiansen et al., 1994) the primers
5'-GGATCCACTTATCAAAAGAATTGGTACC-3' (bases $430-451$ with the BamHI site added) and $5^{\prime}-$ CTCGAGCATCAATTTGTTCAGAAACC-3' (bases 815834 with the $X$ hol site added) were used. The nucleotide sequence of the primers used for amplification of part of the conserved domain of $p 120$ of $M$. hominis PG21 were: $5^{\prime}$ GGATCCATGCAATGGATGCTG-3' (bases 2800-2814 with the BamHI site added) and $5^{\prime}$-CTCGAGCTTTTCAACAGTTAGGCC-3' (bases 3237-3254 with the Xhol site added). For cloning of the PCR product the vector pCRII was used. Transformation of $E$. coli $\mathrm{INV} \alpha \mathrm{F}^{\prime}$ was done as described in the TA-cloning kit (Invitrogen). The recombinant plasmid was cut with $X$ hoI and BamHI. The insert was ligated to the expression vector pGEX-5X-3 and used to transform $E$. coli XL1-Blue. The recombinant $E$. coli XL1-Blue was induced with IPTG $(0.4 \mathrm{mM})$ for $2 \mathrm{~h}$ and harvested by centrifugation at $6000 \mathrm{~g}$ for $15 \mathrm{~min}$. The pellet was washed twice in PBS, resuspended in PBS with $1 \%$ Triton X-100 and sonicated on ice for $5 \mathrm{~s}$ at $50 \mathrm{~W}$. The fusion protein was purified by using glutathione beads according to the supplier's instructions (Pharmacia). The protein was eluted in Spin-X tubes (Costar). The fusion protein was diluted in PBS and used for immunization of rabbits.

Polyclonal antibodies (pAbs). Rabbits were immunized intramuscularly with $10 \mu \mathrm{g}$ antigen emulsified in Freund's incomplete adjuvant (Difco) on days 1, 5, 7, 11, 13 and 18 . Intravenous booster injections without Freund's incomplete adjuvant were given on days 39,49 and 55 . On day 68 the rabbits were killed and bled (pAb 121).

Hyperimmune anti-M. hominis PG21 rabbit serum was from the International Mycoplasma Reference Centre, Aarhus, Denmark.

SDS-PAGE and immunoblotting. Proteins from $M$. hominis 

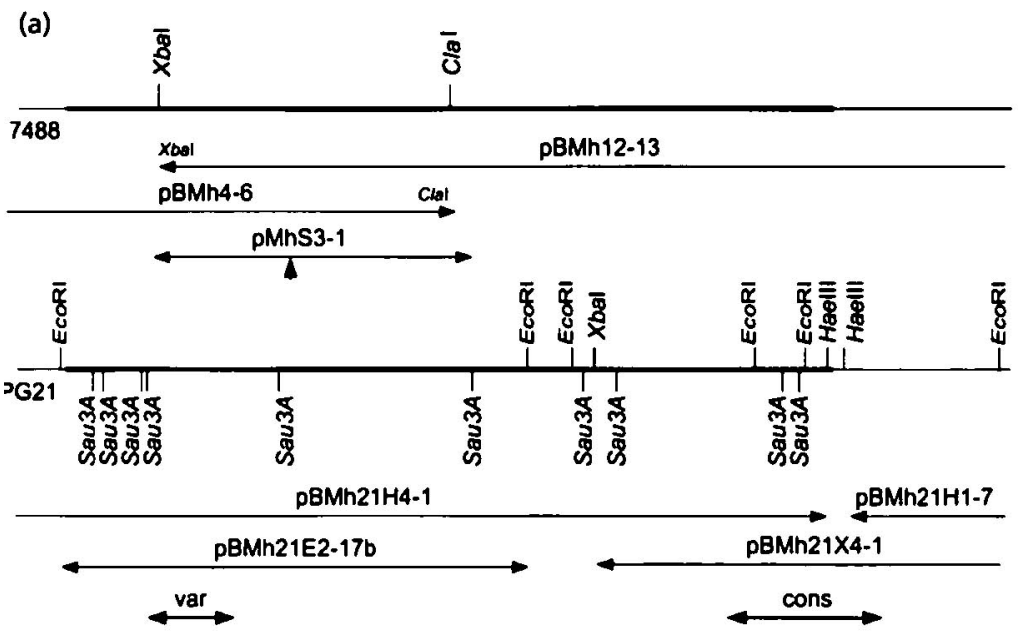

(b)

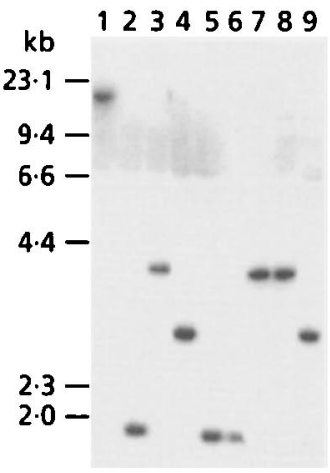

(c)

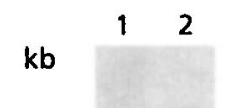

$4 \cdot 4-$

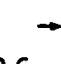

$2 \cdot 6-$
Fig. 1. (a) Restriction map of p120 from $M$. hominis PG21 showing the location of the clones from strains 7488 and PG21. $M$. hominis 7488 probes: pBMh4-6 (Clal clone), and position of $\mathrm{Clal}$ and $\mathrm{Xbal}$ sites used for subcloning; pBMh12-13 (Xbal clone); and pMhS3-1 (Sau3A clone from the pEX library of $M$. hominis 7488 DNA). $M$. hominis PG21 clones: pBMh21H4-1, pBMh21H1-7, pBMh21E2-17b and pBMh21X4-1. The $M$. hominis PG21 restriction map is shown with positions of EcoRI, HaellI, Sau3A and Xbal cleavage sites. Bold lines: open reading frame of $p 120$. Arrowhead, position of UGA codon which in $E$. coli is a stop codon that prevents further translation of the fusion protein; var, position of the hypervariable domain encoding the fusion protein; cons, position of the constant part of p120 encoding the fusion protein. (b) Southern blotting of PG21 DNA cleaved with restriction endonucleases and probed with pBMh7-1 located between the $X$ bal and Clal sites shown on the $\mathbf{7 4 8 8}$ restriction map in (a). PG21 DNA was cleaved with: 1, Clal; 2, Clal-EcoRl; 3, Clal-Haelll; 4, Clal-Xbal; 5, ECoRI; 6, EcoRI-Haelli; 7, Haelli; 8, Haelll-Kpnl; 9, HaellI-Xbal. The positions of standard markers are shown on the left. (c) Northern blot of total RNA from: 1, $M$. hominis PG21; 2, $M$. hominis 7488. The probe pBMh21E2-17b was used for hybridization. The positions of standard markers are shown on the left. The arrow indicates the position of the $3.2 \mathrm{~kb}$ mRNA. cultures harvested in the exponential growth phase, or purified recombinant fusion proteins, were suspended in SDS sample buffer [62.5 mM Tris/ $\mathrm{HCl}$ pH 6.8, $10 \%$ (v/v) glycerol, $2.3 \%$ $(\mathrm{w} / \mathrm{v})$ SDS, $5 \%(\mathrm{v} / \mathrm{v}) \beta$-mercaptoethanol and $0.05 \%(\mathrm{w} / \mathrm{v})$ bromophenol blue], separated by SDS-PAGE in $10 \%$ gels, then transferred electrophoretically onto nitrocellulose membranes (Schleicher \& Schuell). Coomassie blue staining and immunoblotting were done as described by Birkelund $\&$ Andersen (1988).

Metabolic inhibition assay. pAb 121 (generated against the variable domain of P120 of $M$. hominis PG21) was tested for metabolic inhibition in 96-well microtitre trays as described by Feldman et al. (1992). The hydrolysis of arginine results in an alkaline shift of the $\mathrm{pH}$ of the $\mathrm{BEa}$ medium corresponding to the growth of the mycoplasma cells. This colour change was measured spectrophotometrically at dual wavelength of $540 \mathrm{~nm}$ with the reference set at $620 \mathrm{~nm}$ (NJ2000, Teknunc). The colour change was measured every $8 \mathrm{~h}$ for all samples until the colour change of the control sample (no antibody added) had stabilized. The absorbance values were compared for samples and controls. The inhibition (in \%) was calculated at each time point by comparing absorbance values of samples with and without addition of antibodies, arbitrarily setting the absorbance reading of samples without antibodies added to $0 \%$ inhibition. In addition, metabolic inhibition with pAb 121 was compared to that with hyperimmune $M$. hominis PG21 rabbit serum.

Computer analysis. DNA sequences were analysed using the Genetics Computer Group sequence analysis software package (GCG; Devereux et al., 1984). For pairwise alignment of
DNA or amino acid sequences the program GAP was used with a gap creation penalty of 5 and an extension penalty of $0 \cdot 3$.

\section{RESULTS}

\section{Cloning and sequencing of the p120 homologue gene from $M$. hominis PG21}

The restriction map of the genomic region of M. hominis PG21 containing the $p 120$ gene was deduced by cleavage of genomic DNA of $M$. hominis PG21 DNA with EcoRI, HaeIII and XbaI, using the probes pBMh4-6 [ClaI clone with a $2 \cdot 4 \mathrm{~kb}$ insert and two ClaI-XbaI subclones, pBMh6-1 (located upstream of the XbaI site on the 7488 map), pBMh7-1 (located between the XbaI-Clal sites on the $7488 \mathrm{map}$ )] and pBMh12-13 [XbaI clone with a $6.9 \mathrm{~kb}$ insert and the EcoRI-4 subclone (located between the two distal EcoRI sites on the PG21 map)] (Fig. 1a) from the M. hominis $7488 p 120$ gene for hybridizations (Christiansen et al., 1994) (Fig. 1b). Fragments containing the $p 120$ gene from M. hominis PG21 were obtained by shotgun cloning of EcoRI-, HaelII- and $\mathrm{X} b a \mathrm{I}$-digested genomic DNA. Four overlapping clones were identified (Fig. 1a) and used for bidirectional sequencing. The sequence of the M. hominis PG21 p120 homologue is shown in Fig. 2. An open reading frame of $3 \cdot 2 \mathrm{kbp}$ was identified.

The sequence of the $M$. hominis PG21 $p 120$ showed an overall identity of $91 \%$ to the M. hominis $7488 p 120$ 


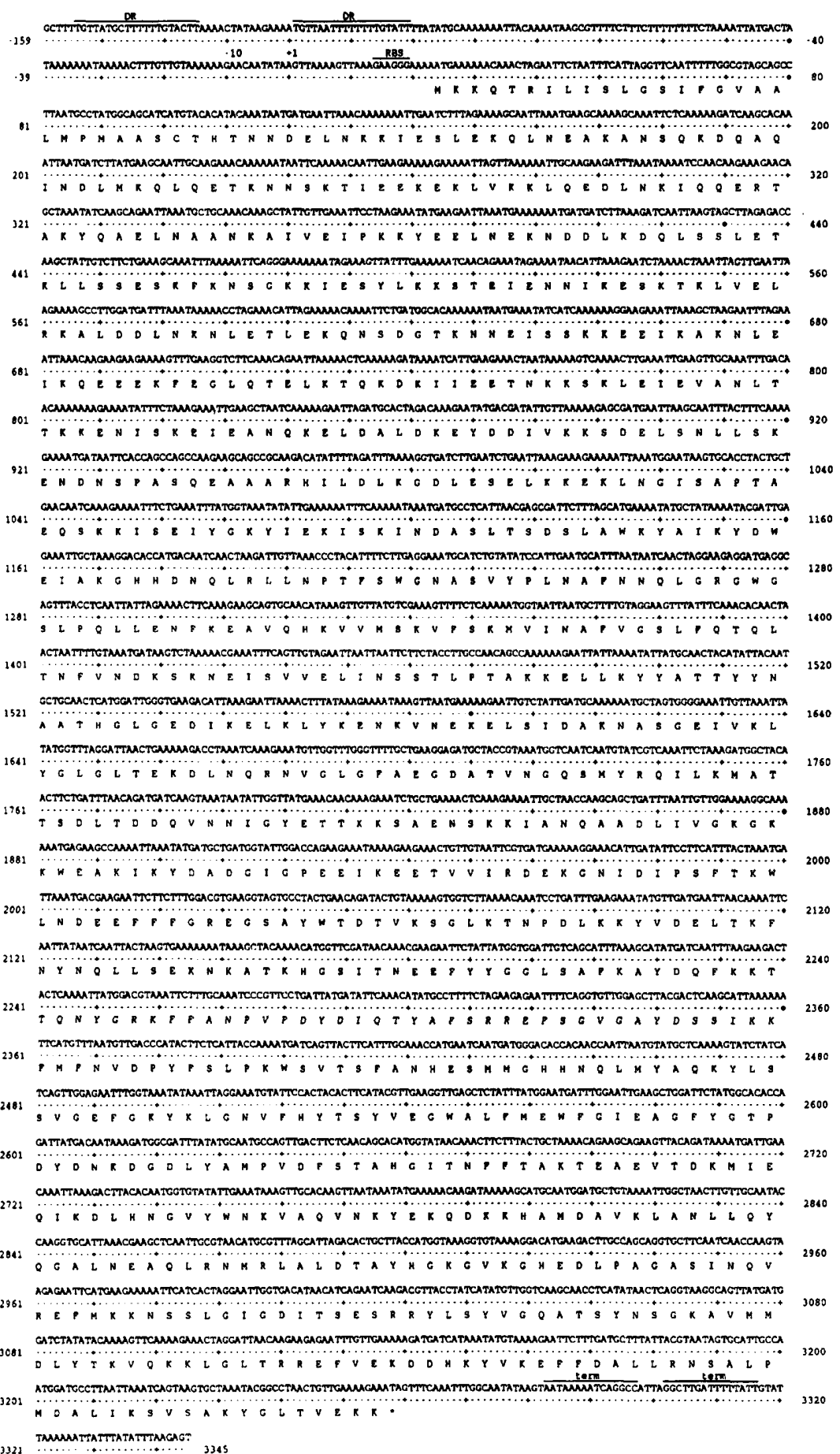

Fig. 2. DNA sequence of the $M$. hominis PG21 p120 gene. A direct repeat is indicated by DR; the ribosome-binding site is marked RBS; 'term' indicates the potential terminating structure. sequence but the sequence divergence was clustered. A hypervariable region was located between bases 401 and 997, and two semivariable regions were located between bases 1194-1467 and 2040-2142 in the central part of the gene. All other regions were very highly conserved. A comparison of the deduced amino acid sequences is shown in Fig. 3. The pronounced sequence variation was maintained at the amino acid level. The length of the hypervariable domain was identical in the two sequences. In the semivariable domain 1 two small deletions were observed, but these did not change the reading frames. The overall similarity was $90 \%$ and the identity was $85 \%$. In the hypervariable domain the identity was $54 \%$.

\section{Detection of mRNA from M. hominis PG21}

Transcription of $p 120$ from $M$. hominis PG21 was detected by Northern blotting. An mRNA $3 \cdot 2 \mathrm{~kb}$ in size was found using pBMh21E2-17b as probe. In addition 


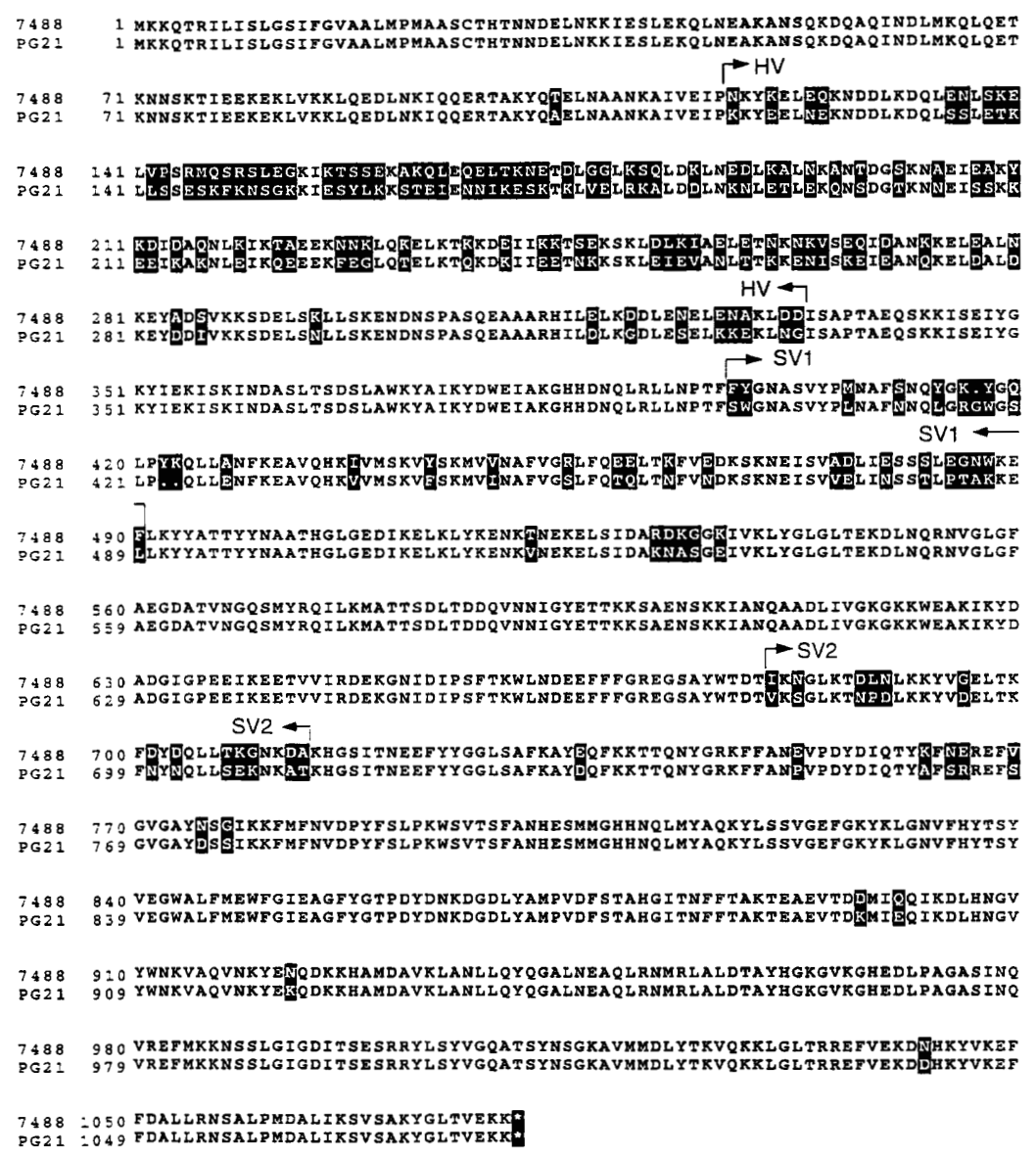

Fig. 3. Alignment of deduced amino acid sequences of P120 from $M$. hominis strains 7488 (top) and PG21. Arrows enclosing HV indicate the position of the hypervariable domains (aa nos 118 and 333); arrows enclosing SV1 and SV2 indicate the positions of the two semivariable domains (aa nos 398-489 and 680-713, respectively). Black boxes indicate non-identical amino acids.

an mRNA fragment or degradation product of $2 \cdot 8 \mathrm{~kb}$ was detected (Fig. 1c).

\section{Demonstration of P120 in M. hominis isolates}

To detect whether P120 was expressed in M. hominis PG21, polyclonal antibodies were generated against part of the hypervariable domain (aa 135-273). A PCR product covering part of the hypervariable domain of M. hominis PG21 p120 was made with the primers described above. The PCR product was cloned, sequenced, and inserted into the expression vector pGEX5x-3. Purified fusion protein was used for immunization. The resulting antiserum, pAb 121, recognized a $120 \mathrm{kDa}$ protein in immunoblots of wholecell proteins of 11 of $18 \mathrm{M}$. hominis isolates, including PG21 (Table 2). The reaction with pAb 121 was compared to the reactivity with $\mathrm{mAb} 26.7 \mathrm{D}$ (Fig. 4a, b). Six of the isolates reacted with both antibodies, five reacted only with pAb 121, and four only with mAb 26.7D. In addition to P120 (arrows) both antibodies reacted with additional bands. This could be due either to nonspecific binding, to reactivity with degradation products of P120 or to the presence of antibodies reacting with these products. Preimmune rabbit serum did not show a similar reaction. For $\mathrm{mAb} 26.7 \mathrm{D}$ repeated subclonings of the hybridoma cells did not change in reaction pattern, suggesting that the binding of $\mathrm{mAb} 26.7 \mathrm{D}$ to the lower molecular mass bands was due to immunoglobulin-binding properties of these antigens. Two isolates (V2785 and 5941) did not express a $120 \mathrm{kDa}$ protein as determined by Coomassie Blue staining of proteins separated by SDS-PAGE (Fig. 4c, lanes 2 and 13). Thus, of the isolates that produced a $120 \mathrm{kDa}$ protein, only M. hominis 7357 (Fig. 4, lanes 17) did not react with any of the antibodies. Antiserum $\mathrm{pAb}$ 121 did not inhibit metabolism of M. hominis PG21.

The fusion protein of the $\mathrm{pEX}$ clone (pMhS3-1, Fig. 1a) from $M$. hominis 7488 reacted with $\mathrm{mAb} 26.7 \mathrm{D}$ (Christiansen et al., 1994). The epitope could be located between the start of the fusion protein (aa 131) and the first UGA codon, which in $E$. coli codes for stop but in mycoplasmas for tryptophan (aa 371) (Yamao et al., 1985), (Fig. 1a). Since mAb 26.7D reacted with the fusion proteins spanning most of the hypervariable domains (in PG21 aa 135-273) and did not react with P120 of PG21, the epitope is thus located at this part of P120 (aa 131-273) (Fig. 1a, Fig. 3).

\section{Immunogenicity of the hypervariable domain}

To analyse the hypervariable domain of P120 for antigenicity, fusion proteins containing this domain from PG21 (aa 135-273) and from 7488 (aa 137-271) were purified and used as antigens in immunoblots 
Table 2. Classes of $M$. hominis isolates based on reaction with mAb 26.7D, pAb 121 and Tru9l cleavage patterns of the hypervariable domain of P120

\begin{tabular}{|c|c|c|c|c|c|}
\hline & Isolate* & From $\dagger$ & $\begin{array}{c}\text { Reaction } \\
\text { with } \\
\text { mAb 26.7D } \neq\end{array}$ & $\begin{array}{c}\text { Reaction } \\
\text { with } \\
\text { pAb 121 }\end{array}$ & $\begin{array}{c}\text { Tru9I } \\
\text { cleavage } \\
\text { pattern\$ }\end{array}$ \\
\hline \multirow[t]{7}{*}{ Class 1} & $1893^{1}$ & C & - & + & 1 \\
\hline & $7357^{1}$ & C & - & - & 1 \\
\hline & $4712^{1}$ & $\mathrm{C}$ & - & + & 1 \\
\hline & $93^{2}$ & C & - & + & 1 \\
\hline & $7808^{1}$ & $\mathrm{FU}$ & - & + & 1 \\
\hline & V2785 & $\mathrm{O}$ & NP & NP & $1 \operatorname{var} A$ \\
\hline & PG $21^{2}$ & $\mathrm{C}$ & - & + & 1 varB \\
\hline \multirow{5}{*}{ Class 2} & DC63 ${ }^{2}$ & $\mathrm{O}$ & + & - & 2 \\
\hline & $132^{2}$ & C & + & - & 2 \\
\hline & $7488^{1}$ & C & + & - & 2 \\
\hline & $5941^{1}$ & C & NP & NP & $2 \operatorname{varA}$ \\
\hline & $3105^{1}$ & C & + & - & $2 \operatorname{varB}$ \\
\hline \multirow[t]{4}{*}{ Class 3} & $\mathrm{SC} 4^{2}$ & MU & + & + & 3 \\
\hline & $\mathbf{P} 2^{2}$ & UUT & + & + & 3 \\
\hline & $\mathrm{P}^{2}{ }^{2}$ & UUT & + & + & 3 \\
\hline & $\mathrm{P} 71^{2}$ & UUT & + & + & $3 \operatorname{var} A$ \\
\hline \multirow{2}{*}{ Class 4} & $3849^{1}$ & C & + & + & 4 \\
\hline & $6188^{1}$ & C & + & + & 4 \\
\hline
\end{tabular}

* 1, Isolates selected to show heterogeneity (Andersen et al., 1987); 2, clinical isolates collected over a 3 month period (Christiansen $\&$ Andersen, 1988).

†C, cervix; FU, female urethra; MU, male urethra ; O, oral cavity; UUT, upper urinary tract.

$\ddagger$ NP, No protein.

\Var, variant.

probed with 21 sera positive for M. hominis. Twelve of the 21 sera reacted with the variable domain of P120 from 7488 (Fig. 5a). In contrast, only four sera reacted with the variable domain of P120 from PG21. Three of these sera also reacted with the variable domain of the 7488 fusion protein (Table 3). The constant part (aa 926-1077) of P120 was also purified as a recombinant fusion protein. None of the sera reacted with this fusion protein. All sera reacted with several proteins from both M. hominis PG21 and 7488. However, the intensity of the bands and the band patterns obtained with the different sera differed extensively (Fig. 5b). In addition, when the reactivity of the two different strains with the same serum was analysed, different band patterns were seen.

\section{Variation of $p 120$ in other M. hominis isolates analysed by PCR}

To analyse variation in the $p 120$ gene in other $M$. bominis isolates PCR was performed. On the basis of the alignment of $p 120$ from $M$. hominis PG21 and 7488, primer sets covering conserved or variable regions were selected (Table 1). Six isolates were examined, two of which reacted with mAb 26.7D only (DC63 and 7488), two which reacted only with pAb 121 (PG21 and 4712), one which reacted with both antibodies (SC4) and one which did not express a detectable $120 \mathrm{kDa}$ protein (V2785) (Table 2). The results of the analyses are shown in Table $4(a, b)$.

Primers from the conserved regions [the promoter region (bp -387 to 97) and from the distal part of the gene (bp 2583 to 3084)] amplified products from all isolates. Primers located in the variable domains amplified products from a restricted number of isolates (Table $4 a, b)$. Primers located within the semivariable domains amplified products from most isolates, but often with weak bands, suggesting some mismatch of the primers. Pronounced discrimination was seen when primers from the hypervariable domain were used. Primers from 7488 only amplified DNA from DC63, while the primers specific for the hypervariable domain of PG21 allowed amplification of DNA from SC4 and 4712.

To determine the sequence variability, PCR products from three regions - the promoter region $(b p-387$ to 97), part of the hypervariable domain (bp 316 to 876) and the distal part of the conserved domain (bp 2583 to 3084 ) of the $p 120$ gene - were analysed. The PCR fragments from SC4 and V2785 were cloned and sequenced and compared with the sequences from PG21 and 7488 . The region $5^{\prime}$ to the putative promoter showed 


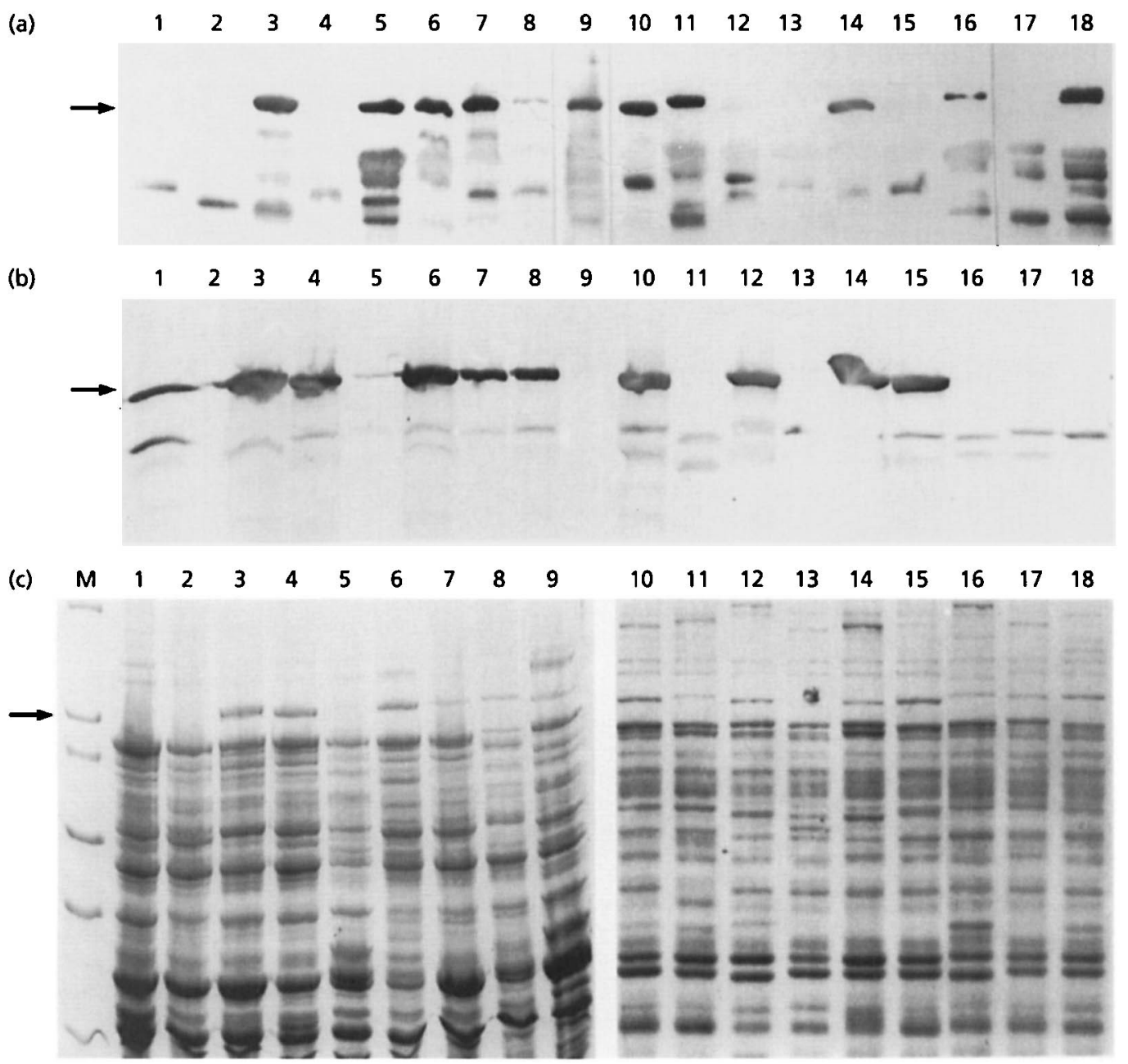

Fig. 4. Total cell proteins of $M$. hominis strains $(1, \mathrm{DC} 63 ; 2, \mathrm{~V} 2785 ; 3, \mathrm{SC} 4 ; 4,132 ; 5,93 ; 6, \mathrm{P} 2 ; 7, \mathrm{P7} ; 8, \mathrm{P71} ; 9, \mathrm{PG} 21 ; 10$, $3849 ; 11,7808 ; 12,7488 ; 13,5941 ; 14,6188 ; 15,3105 ; 16,1893 ; 17,7357 ; 18,4712)$ were separated by SDS-PAGE (10\% acrylamide), transferred to nitrocellulose and reacted with (a) pAb 121 and (b) mAb 26.7D. (c) Coomassie-Blue-stained gel showing the presence of the $120 \mathrm{kDa}$ protein in all strains apart from V2785 and 5941 (lanes 2 and 13). M, size markers: myosin (200 kDa), $\beta$-galactosidase (116.3 kDa), phosphorylase $b(97.4 \mathrm{kDa})$, bovine serum albumin (66.3 kDa), glutamate dehydrogenase $(55.4 \mathrm{kDa}$ ) and lactate dehydrogenase $(36.5 \mathrm{kDa}$ ) (Mark 12, Novex). Arrows indicate the position of the $120 \mathrm{kDa}$ protein.

a high degree of conservation (up to $4 \%$ difference) although there were small insertions and deletions. Immediately $5^{\prime}$ to the putative promoter V2785 differed from the three other isolates with the deletion of guanines at positions -72 and -74 ; and two cytosines at positions -63 and -67 were deleted from the 7488 sequence. The first 74 bp of $p 120$ were identical in PG21, 7488 and V2785, and in SC4 only one nucleotide was changed. The distal part of the genes was also highly conserved, with less than $1 \%$ variation and no deletions.

The hypervariable domain (bp 316-876) from SC4 showed pronounced variability when compared to PG21 and 7488 . When the deduced amino acid sequences were compared (from aa 135 to 284) the sequence identities were $70 \%$ between SC4 and PG 21 , and $52 \%$ between SC4 and 7488.

\section{PCR amplification of the hypervariable domain from $18 M$. hominis isolates}

To determine whether the variability seen in the hypervariable domain would fall into specific classes, the hypervariable domain of $18 \mathrm{M}$. hominis isolates (DC63, V2785, SC4, 132, 93, P2, P7, P71, PG21, 3849, $7808,7488,5941,6188,3105,1893,7357$ and 4712 ) was analysed. The hypervariable domain was amplified using primers flanking this domain (Table 1). A DNA fragment of approximately $700 \mathrm{bp}$ was amplified from all isolates (Fig. 6a). When the PCR products were cleaved with $X b a \mathrm{I}$ four different digestion patterns were seen (Fig. 6b). Seven isolates (V2785, 93, PG21, 7808, 1893,7357 and 4712 ) were not cut with $\mathrm{XbaI}$, six isolates (DC63, 132, P71, 7488, 5941 and 3105) were cleaved once, three isolates (SC4, P2 and P7) were also cleaved 
(a)

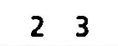

456
$8 \quad 9 \quad 1011121314151617 \quad 1819$

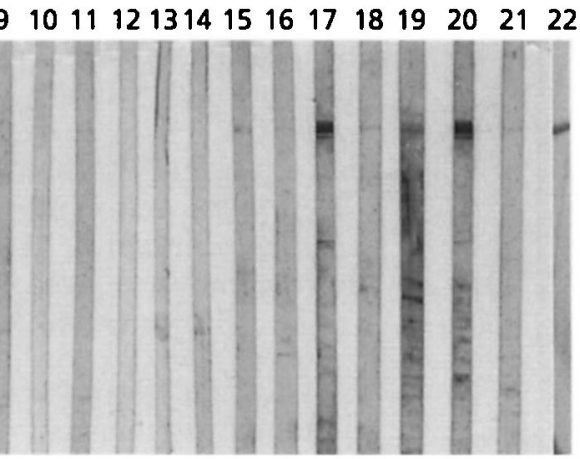

(b) 122345

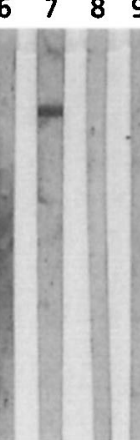

6 $\begin{array}{llllllllllllllll}7 & 8 & 9 & 10 & 11 & 12 & 13 & 14 & 15 & 16 & 17 & 18 & 19 & 20 & 21 & 22\end{array}$
Fig. 5. Proteins were separated by SDSPAGE (10\% acrylamide), transferred to nitrocellulose membranes and immunoblotted with human sera from the WHO Reference Bank for Reproductive Immunology. Lanes contained the following serum samples: 1,$11 ; 2,21 ; 3,28 ; 4,54 ; 5$, $59 ; 6,78 ; 7,93 ; 8,100 ; 9,124 ; 10,127 ; 11$, $148 ; 12,169 ; 13,177 ; 14,203 ; 15,205 ; 16$, $246 ; 17,255 ; 18,301 ; 19,315 ; 20,332 ; 21$. 338. (a) Purified fusion protein from the hypervariable domain of strain 7488 . Lane 22 shows Amido-Black staining of a nitrocellulose strip containing the fusion protein. The arrow indicates the position of the fusion protein. (b) Whole-cell proteins of 7488. Lane 22 was reacted with hyperimmune rabbit serum immunized with PG21. The arrow indicates the position of the $120 \mathrm{kDa}$ protein. once, but at different sites, while two isolates (3849 and 6188) were cut twice by XbaI.

The PCR products from the $18 \mathrm{M}$. hominis isolates were further analysed by cleavage with Tru9I, which cleaved the amplified fragments of PG21 and 7488 frequently and at different positions, thus producing different band patterns. Four distinct classes, which correlated with those identified by $\mathrm{XbaI}$ digestion, were seen with Tru9I digestion. The groupings of the $18 \mathrm{M}$. hominis isolates are shown in Fig. $6(\mathrm{c})$ and Table 2. In the first class, 93 and 1893 had identical restriction endonuclease cleavage patterns while 7357,4712 and 7808 differed in that a band of $75 \mathrm{bp}$ was missing and two smaller bands of less than $50 \mathrm{bp}$ were seen. V2785 shared some fragments (three of the five larger bands) but also showed some band variation. The band pattern of PG21 deviated most. In the second class, DC63, 132 and 7488 were identical while 5941 and 3105 shared most of the DNA fragments with this class. In the third class, SC4, P2 and P7 had identical cleavage patterns while P71 share three bands with this class. A fourth class was formed by 3849 and 6188 , which appeared to be identical.

To determine the variability of the hypervariable domain of $p 120,514$ bp of the DNA sequence (bp 361-875) from DC63, P2, SC4 and V2785 was compared with the sequence of 7488 and PG21. The DNA sequences of 7488 and DC63 were identical, as were those of P2 and SC4; PG21 and 93 had a sequence identity of $90 \%$, while SC4 and DC63, which were classified in different classes, showed sequence identity of only $62 \%$. V2785 had $91 \%$ sequence identity with PG21, and had an insertion of $7 \mathrm{bp}$ in the hypervariable domain. The deduced amino acid sequences (bp 361-875) are shown in Fig. 7. Since the insertion in V2785 produced a change in reading frame resulting in a stop codon immediately after the insertion this sequence is not shown. None of the other isolates which were sequenced differed in the number of base pairs and none of the base changes resulted in stop codons. The differences in amino acid sequences are summarized in Table 5. Differences between isolates in distinct classes ranged from 23 to $35 \%$ at the nucleotide level and from 36 to $57 \%$ at the amino acid level, while differences between isolates in the same class ranged from 0 to $10 \%$ at the nucleotide level and from 0 to $11 \%$ at the amino acid level.

\section{DISCUSSION}

The M. hominis P120 is a variable surface-exposed membrane protein. The surface exposure of P120 was previously demonstrated by immunoelectron microscopy using $\mathrm{mAb} 26.7 \mathrm{D}$ as a probe (Christiansen et al., 1994). P120 of $M$. hominis displays antigenic variation but the size of the protein appears constant. The intensity of the $120 \mathrm{kDa}$ band seen on Coomassie-Bluestained gels varied between strains (Fig. 4c), suggesting the existence of a genetic switch that may regulate expression of the gene. However, this remains to be determined.

P120 may be useful as an antigenic marker. To analyse 
Table 3. Reaction of selected human sera with cloned, expressed hypervariable domains of P120 and whole-cell proteins

Purified recombinant fusion proteins of the variable part of P120 from M. hominis 7488 (Var 7488) and PG21 (Var PG21), and whole-cell proteins of $M$. hominis PG21 and 7488, were solubilized in SDS-sample buffer and separated by SDS-PAGE. Immunoblotting of the transferred proteins were done with 21 serum samples (diluted $1: 50$ ). - , No reaction; $(+)$, weak reaction; + , positive reaction; ++ , strong positive reaction.

\begin{tabular}{|c|c|c|c|c|}
\hline $\begin{array}{l}\text { WHO } \\
\text { serum }\end{array}$ & $\begin{array}{c}\text { Var } \\
7488\end{array}$ & $\begin{array}{c}\text { Var } \\
\text { PG21 }\end{array}$ & PG21 & 7488 \\
\hline 11 & - & + & + & ++ \\
\hline 21 & + & + & + & + \\
\hline 28 & + & + & + & + \\
\hline 54 & - & - & $(+)$ & $(+)$ \\
\hline 59 & + & + & ++ & + \\
\hline 78 & - & - & ++ & ++ \\
\hline 93 & ++ & - & ++ & ++ \\
\hline 100 & - & - & $(+)$ & $(+)$ \\
\hline 124 & - & - & + & + \\
\hline 127 & - & - & + & + \\
\hline 148 & + & - & + & + \\
\hline 169 & - & - & ++ & ++ \\
\hline 177 & - & - & + & + \\
\hline 203 & - & - & + & + \\
\hline 205 & + & - & $(+)$ & ++ \\
\hline 246 & + & - & + & + \\
\hline 255 & ++ & - & + & ++ \\
\hline 301 & + & - & + & + \\
\hline 315 & + & - & + & + \\
\hline 332 & ++ & - & + & ++ \\
\hline 338 & + & - & + & + \\
\hline
\end{tabular}

whether this was the case we have determined the genetic basis for variation of the P120 M. hominis antigen and demonstrated that the hypervariable part of the protein is recognized by the human humoral immune response. The isolates used in this study have been described previously (Christiansen \& Andersen, 1988). Strains shown in Fig. 4, lanes 1-9, were selected to represent a wide coverage with respect to anatomical site of isolation, association with diseases and geographical origin. The other strains (Fig. 4, lanes 10-18) were selected as a homogeneous group; these isolates were fresh clinical isolates collected locally over a 5 month period in 1986. The sera were collected internationally for WHO from infertile couples. It is thus unlikely that there is any correlation between the human sera and the M. hominis isolates used in this study.

Antibodies from seropositive patients recognized the hypervariable domain of P120 from 7488 more frequently and with stronger reaction than that of PG21. This observation is in agreement with the finding that 7488 belongs to a class of isolates in which the $p 120$ gene is relatively conserved, with three of the isolates showing identical band patterns when the hypervariable part of the gene was cleaved with Tru9I, and two showing considerable similarity. In contrast, the hypervariable domain from PG21 had a unique band pattern within its class, with only few identical bands (Fig. 6). The carboxy-terminal $43 \mathrm{kDa}$ of P120 is constant; however, this region was not recognized by any of the sera tested, and thus is not useful for serology.

The different classes of isolates identified by restriction endonuclease analysis of the hypervariable domain correlated with their reactivity with $\mathrm{mAb} 26.7 \mathrm{D}$ and pAb 121 (Table 2). The strains within class 1 reacted with pAb 121 but not with mAb 26.7D, apart from V2785, which did not express the protein, and 7357, which did not react with either of the antibody preparations. In class 2 , strains reacted with $\mathrm{mAb} 26.7 \mathrm{D}$ but not with pAb 121, apart from 5941, which did not express the protein. All strains from classes 3 and 4 reacted with both antibody preparations. Thus only one strain, 7357 , had reactivity that did not correlate with the class predicted by restriction endonuclease analysis. Although there was a distinct pattern within each class, individual variation was observed for some of the members. Sequencing of five of the PCR products from three classes confirmed the suggestion of significant differences between the classes.

It is notable that all four isolates in class 3 were from the urinary tract. P2 was isolated from a case of acute pyelonephritis, $\mathrm{P} 7$ from a case of chronic pyelonephritis, and P71 from the urinary tract of a patient with noninfectious urinary tract disease (Thomsen, 1978). SC4 was isolated from the male urethra (Hollingdale \& Lemcke, 1970). The significance of this observation has not been determined, but the first three isolates were from Danish patients and the fourth isolate was from England, indicating that geographically distinct isolates may have identical hypervariable sequences. A time span of 9 years separated these isolates. An even larger time span separated the isolates of DC63 (TaylorRobinson et al., 1963) and 7488 (Christiansen \& Andersen, 1988), which also had identical hypervariable sequences.

While the absence of expression of P120 in V2785 could be linked to a $7 \mathrm{bp}$ insertion which shifted the translational reading frame, an explanation for the absence of P120 in 5941 was not found in our studies. The PCR product obtained from amplification of the hypervariable region of 5941 was identical in size to those amplified from all other isolates except V2785. Failure to express $\mathrm{P} 120$ in strain $\mathrm{H} 4$ was associated with a very slow growth rate and formation of nipple-less colonies on agar plates (Sasaki et al., 1989). However, a slow growth rate for V2785 (and for 5941) was not observed in the present study and the colonies appeared identical to those of other isolates.

The isolates examined in this study have also been examined for polymorphism associated with their rRNA 
Table 4. PCR of $M$. hominis strains with primers based on $p 120$ of strains 7488 and PG21

\begin{tabular}{|c|c|c|c|c|c|}
\hline \multirow[b]{2}{*}{ Strain } & \multicolumn{4}{|c|}{ (a) PCR with primers based on p120 of 7488} & \multirow[b]{2}{*}{$\begin{array}{l}\text { Conserved } \\
\text { region: bases } \\
\text { 2583-3084 }\end{array}$} \\
\hline & $\begin{array}{l}\text { Promoter } \\
\text { region : bases } \\
-387 \text { to } 97\end{array}$ & $\begin{array}{c}\text { Hypervariable } \\
\text { domain : bases } \\
584-965\end{array}$ & $\begin{array}{c}\text { Semivariable } \\
\text { domain: bases } \\
\text { 948-1392 }\end{array}$ & $\begin{array}{l}\text { Semivariable } \\
\text { domain : bases } \\
2067-2389\end{array}$ & \\
\hline DC63 & + & + & + & + & + \\
\hline V2785 & + & - & + & - & + \\
\hline SC4 & + & - & $(+)$ & $(+)$ & + \\
\hline PG21 & + & - & - & + & + \\
\hline 7488 & + & + & + & + & + \\
\hline 4712 & + & - & $(+)$ & $(+)$ & + \\
\hline \multicolumn{6}{|c|}{ (b) PCR with primers based on $p 120$ of PG21 } \\
\hline & Strain & $\begin{array}{c}\text { Hypervariable } \\
\text { domain: bases } \\
316-876\end{array}$ & $\begin{array}{l}\text { Semivariable } \\
\text { domain: bases } \\
769-1228\end{array}$ & $\begin{array}{l}\text { Semivariable } \\
\text { domain: bases } \\
1102-1668\end{array}$ & \\
\hline & DC63 & - & + & + & \\
\hline & V2785 & - & + & + & \\
\hline & SC4 & + & + & + & \\
\hline & PG21 & + & + & + & \\
\hline & 7488 & - & - & + & \\
\hline & 4712 & + & + & $(+)$ & \\
\hline
\end{tabular}

- , No amplification of a PCR product; $(+)$, weak reaction; + , PCR amplification.

genes (Christiansen \& Andersen, 1988). Although the classifications correlated for some strains (P2, P7 and $1893,7357)$, other strains were not classified as described by Christiansen \& Andersen (1988), indicating the broad heterogeneity within this species. DC63 and 7488 showed identity of the hypervariable domain by DNA sequencing but differed from each other in the $16 \mathrm{~S}$ rRNA gene, which in DC63 lacks an EcoRI cleavage site in both 16S rRNA operons. SC4 differed from P2 in the $23 \mathrm{~S}$ rRNA gene, with a HindIII site missing in one of the two $23 \mathrm{~S}$ rRNA operons. While the variation in the rRNA genes may be explained as genetic drift, the discovery of a hypervariable domain within a surfaceexposed protein indicates that other mechanisms may be responsible for this variation. Since otherwise distant isolates (such as 7488 and DC63) display identity in the hypervariable domains, it could be speculated that such variability could originate by horizontal gene transfer. Evidence for this hypothesis remains to be determined.

Antigenic variation has been observed in several Mycoplasma species and the molecular basis for the antigenic variation has been studied for several such genes. In $M$. pneumoniae sequence divergence of the $170 \mathrm{kDa} P 1$ cytadhesin has been observed. In addition to the gene encoding P1, multiple copies of fragments of the gene are found at different positions of the genome and several regions of the gene contain repeated sequences. On the basis of restriction fragment length polymorphism, isolates of $M$. pneumoniae could be divided into two groups. A region of $500 \mathrm{bp}$, located $640 \mathrm{bp}$ downstream of the start of the open reading frame, was found to display a high degree of sequence variation similar to that observed for P120 of M. hominis. For M. pneumoniae, however, the divergent region could be generated by recombination with gene fragments present in the genome. The recombination events could be facilitated by the presence of the repeated sequences ( $\mathrm{Su}$ et al., 1993). In Mycoplasma genitalium, MgPa, which is homologous to P1 of $M$. pneumoniae, also contains repeated sequences, and multiple copies of gene fragments are present on the genome. The repetitive elements are suggested to be of importance for antigenic variation (Peterson et al., 1995). In the size-variable Vlps in Mycoplasma byorbinis and V-1 in Mycoplasma pulmonis, repetitive elements play a major role in generating antigenic variation (Simmons et al., 1996; Yogev et al., 1995). However, exchange of larger cassettes of DNA does not seem to be important for antigenic variation in these genes.

The presence of a hypervariable domain within an otherwise conserved gene has previously been described in $M$. pneumoniae. The variable region of the ORF6 gene from M. pneumoniae (Ruland et al., 1994) resembles the hypervariable domain of the $p 120$ gene from $M$. hominis in that the homology between two strains changes abruptly from almost $100 \%$ identity to low similarity, including deletions, and back again to almost $100 \%$ identity. Furthermore, it was the $\mathrm{N}$ terminal and C-terminal regions of the ORF6 gene that were conserved. Whether exchange of genetic material 

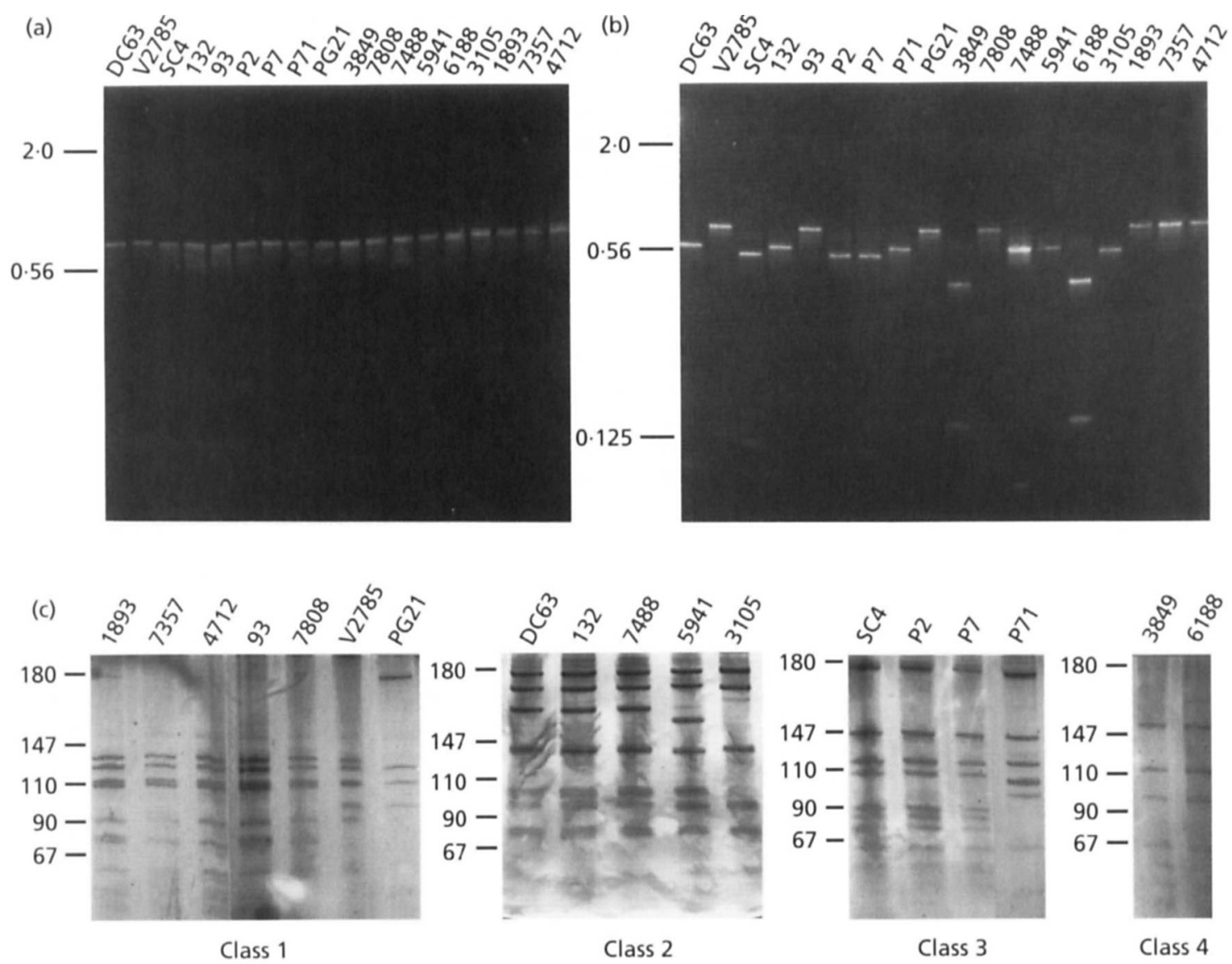

Fig. 6. Analysis of the PCR products of the hypervariable domain of the p120 gene. (a) Agarose gel electrophoresis of entire PCR products from the hypervariable domain (bp 357-1052) of the $M$. hominis strains DC63, V2785, SC4, 132, 93, P2, P7, P71, PG21, 3849, 7808, 7488, 5941, 6188, 3105, 1893, 7357 and 4712; (b) agarose gel electrophoresis of PCR products digested with Xbal; (c) silver-stained $10 \%$ polyacrylamide gel showing PCR products from the hypervariable domain digested with Tru9l.

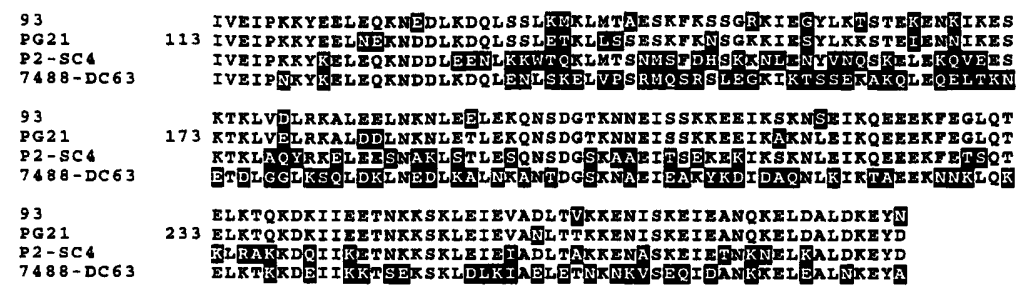

Fig. 7. Multiple alignment of amino acid sequences of part of the hypervariable domain of the $p 120$ gene of PG21, 7488, 93, SC4 and DC63. PILEUP in the GCG package was used for alignment. Alignment was done of the deduced amino acid sequences (aa 113-280). Strains 7488 and DC63, and P2 and SC4 were identical. Black boxes indicate non-identical amino acids. in a specific domain occurs in M. hominis, as suggested for the ORF6 gene in M. pneumoniae (Ruland et al., 1994), remains to be determined. In M. pneumoniae copies of different variable domains are found outside the ORF6 gene. This was not detected for $p 120$ in $M$. hominis.

To our knowledge, this is the first report in which a specific domain of a gene product of $M$. hominis has been identified as target for the immune system. Such domains may be useful in our understanding of gene conversion and gene rearrangements in mycoplasmas. In this study it could not be determined whether specific hypervariable domains could confer additional viability upon the $M$. hominis strains. To determine whether this is the case, isolates known to be pathogenic need to be examined to determine whether antigenic changes occur in response to appearance of antibodies, and consecutive isolates of $M$. hominis need to be collected and analysed for reactivity with serum samples from the same patient. 
Table 5. Differences between nucleic acids and amino acid sequences of hypervariable domains (bp 361-875 and aa 113-280) of p120 of M. hominis strains

$\mathrm{N}$, nucleic acid; A, amino acid. The numbers indicate the number of substitutions per 100 bases or amino acids. Class 1, 93, PG21 and V2785; class 2, 7488 and DC63; class 3, SC4 and P2.

\begin{tabular}{|c|c|c|c|c|c|c|c|c|c|}
\hline \multirow[t]{2}{*}{ Strain } & \multicolumn{2}{|c|}{ DC63/7488 } & \multicolumn{2}{|c|}{ SC4/P2 } & \multicolumn{2}{|c|}{93} & \multicolumn{2}{|c|}{ PG21 } & \multirow{2}{*}{$\frac{\mathrm{V} 2785}{\mathrm{~N}}$} \\
\hline & $\mathbf{N}$ & A & $\mathbf{N}$ & $\mathbf{A}$ & $\mathbf{N}$ & A & $\mathbf{N}$ & A & \\
\hline DC63/7488 & 0 & 0 & 35 & 57 & 34 & 54 & 34 & 51 & 33 \\
\hline $\mathrm{SC} 4 / \mathrm{P} 2$ & & & 0 & 0 & 24 & 36 & 25 & 38 & 23 \\
\hline 93 & & & & & 0 & 0 & 9 & 11 & 10 \\
\hline PG21 & & & & & & & 0 & 0 & 9 \\
\hline V2785 & & & & & & & & & 0 \\
\hline
\end{tabular}

\section{ACKNOWLEDGEMENTS}

This work was supported by the Danish Health Research Council (grants 12-0850-1 and 12-1620-1), Aarhus University Foundation, Novo's Foundation, and Fonden til Lægevidenskabens Fremme. We thank Karin S. Sørensen and Inger Andersen for excellent technical assistance.

\section{REFERENCES}

Andersen, H., Birkelund, S., Christiansen, G. \& Freundt, E. A. (1987). Electrophoretic analysis of proteins from Mycoplasma hominis strains detected by SDS-PAGE, two-dimensional gel electrophoresis and immunoblotting. J Gen Microbiol 133, 181-191.

Birkelund, S. \& Andersen, H. (1988). Comparative studies of mycoplasma antigens and corresponding antibodies. In Handbook of Immunoblotting of Proteins, vol. II, pp. 25-33. Edited by O. J. Bjerrum \& N. H. H. Heegaard. Boca Raton, FL: CRC Press.

Blanchard, A., Yáffez, A., Dybvig, K., Watson, H. L., Griffiths, G. \& Cassell, G. H. (1993). Evaluation of intraspecies genetic variation within the 16S rRNA gene of Mycoplasma hominis and detection by polymerase chain reaction. J Clin Microbiol 31, 1358-1361.

Brown, M. B., Minion, F. C., Davis, J. K., Pritchard, D. G. \& Cassell, G. H. (1983). Antigens of Mycoplasma hominis. Sex Transm Dis 10 (Suppl.), 247-255.

Chomczynski, P. \& Sacchi, N. (1987). Single-step method for isolation by acid guanidinium thiocyanate-phenol-chloroform extraction. Anal Biochem 162, 156-159.

Christiansen, G. \& Andersen, H. (1988). Heterogeneity among Mycoplasma hominis strains as detected by probes containing parts of ribosomal ribonucleic acid genes. Int J Syst Bacteriol 38, 108-115.

Christiansen, G., Ladefoged, S., Hauge, S., Birkelund, S. \& Andersen, H. (1990). Use of monoclonal antibodies for detection of gene and antigen variation in Mycoplasma hominis. In Recent Advances in Mycoplasmology, pp. 535-545. Edited by G. Stanek, G. H. Cassell, J. G. Tully \& R. F. Whitcomb. Stuttgart: Gustav Fisher.

Christiansen, G., Mathiesen, S. L., Nyvold, C. \& Birkelund, S. (1994). Analysis of a Mycoplasma hominis membrane protein, P120. FEMS Microbiol Lett 121, 121-128.

Devereux, J., Haerberli, P. \& Smithies, O. (1984). A comprehensive set of sequence analysis programs for the VAX. Nucleic Acids Res $12,387-395$.
Feldmann, R. C., Henrich, B., Kolb-Bachofen, V. \& Hadding, U. (1992). Decreased metabolism and viability of Mycoplasma hominis induced by monoclonal antibody-mediated agglutination. Infect Immun 60, 166-174.

Grau, O., Laigret, F., Carle, P., Tully, J. G., Rose, D. L. \& Bove, J. M. (1991). Identification of a plant-derived mollicute as a strain of an avian pathogen, Mycoplasma iowae, and its implications for mollicute taxonomy. Int J Syst Bacteriol 41, 473-478.

von Heijne, G. (1989). The structure of signal peptides from bactrial lipoproteins. Protein Eng 2, 531-534.

Hollingdale, M. R. \& Lemcke, R. (1970). Antigenic differences within the species Mycoplasma hominis. J Hyg 68, 469-477.

Krause, D. C. \& Taylor-Robinson, D. (1992). Mycoplasmas which infect humans. In Mycoplasmas, Molecular Biology and Pathogenesis, pp. 417-444. Edited by J. Maniloff, R. N. McElhaney, L. R. Finch \& J. B. Baseman. Washington, DC: American Society for Microbiology.

Ladefoged, S. A. \& Christiansen, G. (1992). Physical and genetic mapping of the genomes of five Mycoplasma hominis strains by pulsed-field gel electrophoresis. J Bacteriol 174, 2199-2207.

Ladefoged, S., Hauge, S., Andersen, H., Birkelund, S. \& Christiansen, G. (1990). Use of monoclonal antibodies for detection of antigen variation in Mycoplasma hominis. In Recent Advances in Mycoplasmology, pp. 634-639. Edited by G. Stanek, G. H. Cassell, J. G. Tully \& R. F. Whitcomb. Stuttgart: Gustav Fisher.

McClenaghan, M., Herring, A. J. \& Aitken, I. D. (1984). Comparison of Chlamydia psittaci isolates by DNA restriction endonuclease analysis. Infect Immun 45, 384-389.

Olson, L. D., Shane, S. W., Karpas, A. A., Cunningham, T. M., Probst, P. S. \& Barile, M. F. (1991). Monoclonal antibodies to surface antigens of a pathogenic Mycoplasma hominis strain. Infect Immun 59, 1683-1689.

Peterson, S. N., Bailey, C. C., Jensen, J. S., Borre, M. B., KIng, E. S., Bott, K. F. \& Hutchison III, C. A. (1995). Characterization of repetitive DNA in the Mycoplasma genitalium genome: possible role in the generation of antigenic variation. Proc Natl Acad Sci USA 92, 11829-11833.

Razin, S. \& Freundt, E. A. (1984). The mycoplasmas. In Bergey's Manual of Systematic Bacteriology, vol. 1, pp. 740-793. Edited by N. R. Krieg \& J. G. Holt. Baltimore: Williams \& Wilkins.

Ruland, K., Himmelreich, R. \& Hermann, R. (1994). Sequence divergence in the ORF6 gene of Mycoplasma pneumoniae. $J$ Bacteriol 176, 5202-5209. 
Sambrook, J., Fritsch, E. F. \& Maniatis, T. (1989). Molecular Cloning: a Laboratory Manual, 2nd edn. Cold Spring Harbor, NY: Cold Spring Harbor Laboratory.

Sanger, F., Nicklen, S. \& Coulson, A. R. (1977). DNA sequencing with chain-terminating inhibitors. Proc Natl Acad Sci USA 74, 5463-5467.

Sasaki, T., Sasaki, Y., Matsumura, T., Oyama, N. \& Koshimizu, K. (1989). Characterization of a strain of Mycoplasma hominis lacking $120 \mathrm{kDa}$ membrane protein isolated from a Vero cell culture. Microbiol Immunol 33, 423-427.

Simmons, W. L., Zuhua, C., Glass, J. L., Simecka, J. W., Cassell, G. H. \& Watson, H. L. (1996). Sequence analysis of the chromosomal region around and within the V-1-encoding gene of Mycoplasma pulmonis: evidence for DNA inversion as a mechanism for $\mathrm{V}-1$ variation. Infect Immun 64, 472-479.

Southern, E. M. (1975). Detection of specific sequences among DNA fragments separated by gel electrophoresis. $J \mathrm{Mol}$ Biol $\mathbf{9 8}$, 503-517.

Su, C. J. \& Baseman, J. B. (1990). Genome size of Mycoplasma genitalium. J Bacteriol 172, 4705-4707.

Su, C. J., Dallo, S. F., Chavoya, A. \& Baseman, J. B. (1993). Possible origin of sequence divergence in the P1 cytadhesin gene of Mycoplasma pneumoniae. Infect Immun 61, 816-822.
Taylor-Robinson, D., Somerson, N. L., Turner, H. C. \& Chanock, R. M. (1963). Serological relationships among human mycoplasms as shown by complement-fixation and gel diffusion. J Bacteriol 85 , 1261-1273.

Thomasen, A. C. (1978). Mycoplasmas in human pyelonephritis: demonstration of antibodies in serum and urine. J Clin Microbiol 8, 197-202.

Tully, J. G. (1983). Cloning and filtration techniques for mycoplasmas. In Methods in Mycoplasmology, vol. 1, pp. 173-177. Edited by S. Razin \& J. G. Tully. New York: Academic Press.

Tully, J. G. (1993). Mollicutes: Mycoplasma pneumoniae and Mycoplasma genitalium. Current status of the Mollicute flora of humans. Clin Infect Dis 17 (Suppl. 1), S2-S9.

Yamao, F., Muto, A., Kawauchi, Y., Iwami, M., Iwagami, S., Azumi, Y. \& Osawa, S. (1985). UGA is read as tryptophan in Mycoplasma capricolum. Proc Natl Acad Sci USA 82, 2306-2309.

Yogev, D., Watson-McKown, R., Rosengarten, R., Im, J. \& Wise, K. (1995). Increased structural and combinatorial diversity in an extended family of genes encoding Vlp surface proteins of Mycoplasma hyorbinis. J Bacteriol 177, 5636-5643.

Received 1 April 1996; revised 13 September 1996; accepted 19 September 1996. 